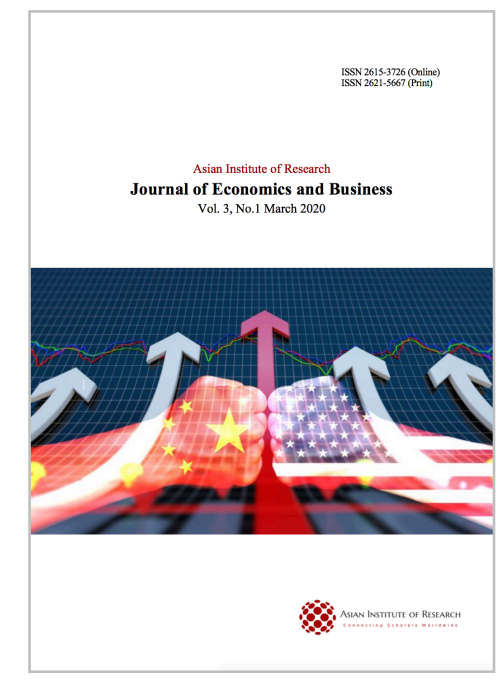

Journal of Economics and Business

Purwadi, Yohanes Slamet, and Manurung, Elvy Maria. (2020), Cafes: New Learning and Knowledge Production Space for Millennial Students. In: Journal of Economics and Business, Vol.3, No.1, 247-253.

ISSN 2615-3726

DOI: 10.31014/aior.1992.03.01.194

The online version of this article can be found at: https://www.asianinstituteofresearch.org/

Published by:

The Asian Institute of Research

The Journal of Economics and Business is an Open Access publication. It may be read, copied, and distributed free of charge according to the conditions of the Creative Commons Attribution 4.0 International license.

The Asian Institute of Research Journal of Economics and Business is a peer-reviewed International Journal. The journal covers scholarly articles in the fields of Economics and Business, which includes, but not limited to, Business Economics (Micro and Macro), Finance, Management, Marketing, Business Law, Entrepreneurship, Behavioral and Health Economics, Government Taxation and Regulations, Financial Markets, International Economics, Investment, and Economic Development. As the journal is Open Access, it ensures high visibility and the increase of citations for all research articles published. The Journal of Economics and Business aims to facilitate scholarly work on recent theoretical and practical aspects of Economics and Business. 


\title{
Cafes: New Learning and Knowledge Production Space for Millennial Students
}

\author{
Yohanes Slamet Purwadi ${ }^{1}$, Elvy Maria Manurung² \\ ${ }^{1}$ School of Cultural Philosophy, Parahyangan Catholic University, Bandung, Indonesia. Email address: \\ yohanes@unpar.ac.id \\ ${ }^{2}$ School of Management, Parahyangan Catholic University, Bandung, Indonesia. Email address: \\ elvymaria@unpar.ac.id
}

Correspondence: Elvy Maria Manurung, School of Management, Parahyangan Catholic University, Bandung 40117, Indonesia. Tel: -. E-mail: elvymaria@unpar.ac.id

\begin{abstract}
The presence of new cafes and restaurants over the last three years in the city have been emerging. These cafes and restaurants do not only serve food or drink but also provide the facility to hang-out, play and study, which are a new phenomenon. This research aims to discover the reason why so many students fulfill these cafes and restaurants. The research conducted to a hundred and eighty-eight students in Bandung city, West Java. Nowadays, the students as consumers are getting voters to choose a place to study, besides in school or campus. This is a qualitative research which done by several observation and interviews. Seven new cafes and restaurants were chosen as research objects. The criteria specified in selecting consumers as informants is the frequency of attendance on the selected cafes and restaurants at least two times a week. A new culture in learning behavior was found. The findings and interpretation show that millennials students prefer to choose café or restaurants as a place for learning while they're eating. They do not want to study in campus or library due to a tedious atmosphere and stressful around campus according to students' opinions. A new definition of "space" (informal space) as a place for learning is found. The café caters to the imagery of erudite, cosmopolitan, and up-to-date youths, all of which are appealing. As a conceptualized space the humble café has transcended beyond its calling as a pit stop and has been reborn as an expression of academic life, combining knowledge production and mood booster, serious knowledge, and playfulness. The illustrious café, make no mistake is the representative space of choice for millennial ( $\mathrm{Z}$ generation) scholars. This research and experiment were carried out in certain areas in West Java. similar research is needed in other cities or other countries. Besides, it is necessary to explore further what factors change millennial students learning behavior, whether only because of a more relaxed atmosphere or other factors. Implications: Similar experiments need to be applied to bring students outside the classroom to get a new atmosphere, mood booster and their participation in class, for other courses in college.
\end{abstract}

Keywords: Cafes, Millennial Students, Learning Behavior, Space, Learning Space

\section{Introduction}

The influence which "space" bears towards perception, mobility and the practices of human behavior is a given, whether it be psychological --perception, cognition, and the process of motivation-- or on an existential plane that, 
in turn, construct responses manifested in a behavior. Numerous studies of college students have revealed a phenomena of mobility, from the typical academic classroom, students have shifted towards another public space: the Café. Underlying this shift is the concept of space and architecture both are intertwined to scientific engineering.

The concept of "space" is meant to be so much more than a "conceived space" or "a scientific space". The rooms within the campus propagate an academic and scientific atmosphere to promote the conception of scholars and scientists. The Campus space is thought more of as a representation of the "knowledge's hegemony", it is however criticized as being too impersonal to the detriment of one's creativity and the stimulation of knowledge. "Space" as a place to study, now has changed away from the formal and an inclination towards informal spaces.

Bandung, which is known as "Paris Van Java", is one of the cities in West Java which has undergone a quite rapid development during the last five years. Bandung is no longer only known as a city that has a lot of students studying or "student city", but will also be known as a tourist or tourism city. Since the construction of Cipularang toll which connects Bandung with Purwakarta regency, Jakarta, and other areas around Bandung, in 2005, the flow of vehicles and local tourists to Bandung increased. Consumer behavior which is increasingly smart and unpredictable is followed by the emergence of hotels, boutiques, distros, restaurants and cafes in Bandung which has increased in recent years. The emergence of cafes and restaurants, not only enjoyed by local tourists, but also by student who studies in Bandung. Nowadays restaurants or cafes in Bandung, are not just places where people eat and drink, but also at the same time a place where many people, especially students are able to hang-out, play, and even study. Society, especially young men in Bandung are now experiencing changes in taste, way of thinking and how to shop due to the presence of boutiques, distros, cafes and new restaurants.

This phenomenon of developing Bandung does not only produce an impact on the economic field but also on the socio-cultural aspects of the user community. A lot of research in Bandung has been done to find the impact of the rise of cafes, boutiques and distros that provide fashion and culinary products to urban economic development, but not many have focused on the creativity of young entrepreneurs and the social and cultural development of the user community. Other research on the presence of cafes, coffee shops, and other "hangout" places in Indonesia has been done in Yogyakarta (Central Java) by Iwan Pribadi (2015), as a form of change of the community lifestyle. The results indicate that the presence of coffee shops in Yogyakarta is no longer dominated by men or fathers only, but also by women. Today's coffeehouse has provided a new "space" for diverse visitors - who come to enjoy the interaction, and also eat and drink. Another similar research was conducted by Pramita, D.A., and Pinasti, V.I.S. (2016) that focus on the habit of "hanging out" of college students in coffee shops in Yogyakarta. The aspects studied in the research, again, emphasize the lifestyle of students in Yogyakarta. Research on the lifestyle of students in the city of Bandung has also been done by Fauzi, A. et.al. (2013) and Wahidah on the objects of places such as pubs or cafes (known as "dugem" or"dunia gemerlap" in Indonesian language) that open at night and usually just close in the morning in Bandung.

Some research on the change of mindsets and lifestyles of young people in Indonesia as described above, has not focused and completely revealed what has happened and changed with young people in Bandung for the last five years. What kind of creativity should appear and be shown by the entrepreneur to make his business survive, as well as changes in socio-cultural construction as what happens to the people of Bandung in general. The aforementioned matters make this study different from other related studies. This research is directed to answer two big questions as follows: (i) How culinary development during the last five years has affected the creativity of young entrepreneurs in Bandung?, and (ii) What changes have occurred to users/consumers in Bandung? This research aims to answer both questions.

\section{Importance of the Problem}

State why the problem deserves new research. For basic research, the statement about importance might involve the need to resolve any inconsistency in the results of past work and/or extend the reach of a theoretical formulation. For applied research, this might involve the need to solve a social problem or treat a psychological disorder. When research is driven by the desire to resolve controversial issues, all sides in the debate should be represented in balanced measure in the introduction. Avoid animosity and ad hominem arguments in presenting 
the controversy. Conclude the statement of the problem in the introduction with a brief but formal statement of the purpose of the research that summarizes the material preceding it. For literature reviews as well as theoretical and methodological articles, also clearly state the reasons that the reported content is important and how the article fits into the cumulative understanding of the field.

Historical-pedagogically wise, our founding father of education Ki Hajar Dewantara, he himself preferred to advocate the term "taman" (garden) in lieu of "school". This denotes a pronounced aspect of "playfulness" in learning, as opposed to pedantic. The essential concept of "taman" by definition is a space which accommodates the possibility of exploring: the dialectic process between student and rational knowledge all the while enabling a sense of liberative "play". Most of these requirements have been fulfilled by the public space all the while offering an ambience of merriment, intimate learning, and good old fun. None of which are to be found in the traditionally constrictive environment of the "scientific space" provided by the campus, thus the motive of exodus away from the classroom to hangout places such as cafés. Not only are these locales essentially a space socially produced they further encourage social reproduction: cafés were first introduced to market mood and relaxation. These favorable environmental qualities have led cafés to ultimately be applied for the purpose of knowledge production. This means, college students are using cafés as non-academic spaces to produce knowledge simply by virtue of pleasant atmosphere, "fun".

Therefore, the construction of areas spatially is certain to affect the mobility, simultaneously the mentality of its occupants, mobility away from the academic space to a "liberative" space, mobility shunning the impersonal cubicle to the adoption of the cozy alternative. This all creates what Henri Lefebvre designates as a "social space production" that is to say the production relations between rooms spatially and "fresh" actions. In other words, "social space is formed by social action, be they individual or collective. It is none other than social action which gives "meaning" as to how a spatial room is conceptualized by those occupying and inhabiting aforementioned space. Social space production follows how social practices manifests through the perception of the environment, made through networks which connect social activities like work, private life and leisure.

\section{Method}

This study was conducted using a qualitative method called ethnography. Ethnographic method begins with the science of anthropology which emphasizes the observation of the social behavior of society in a particular area to gain understanding and interpretation of the empirical phenomenon that occurs. The present use of ethnographic methods has grown broadly and is used in other sciences including business and economics.

As "a portrait of people", according to Haris and Johnson in Gunawan, I. (2015), is the simplest ethnographic deficit. In a broader sense, ethnography means "written description of a particular culture -the customs, belief, and behavior-based on information collected through fieldwork." Therefore, ethnography is an inductive method of research that puts the researcher's sense of reality (emphasizing subjectivity) --a process of deep thinking-- and an interpretation of concepts found by researchers. Not infrequently a researcher will also enter the field and mingle with the object which is studied, be a participant observation.

In this study there are two groups that become the object to be observed, namely:

(i) a group of young entrepreneurs who run a fashion or culinary business in Bandung

(ii) Consumers (users) who enjoy products sold by businesses run by young entrepreneurs.

The author enter into the object studied and observes directly as a participant-observer. There are several ways to obtain data, as follow: (i) spreading 150 questionnaires to get key points about what affects user/consumer behavior and decisions, (ii) focus group discussions (FGDs) to confirm the results of data processing from the incoming questionnaires, and (iii) interviewing business owners which are young entrepreneurs in Bandung. Therefore, data analysis in this study is an interpretative meaning obtained, mainly derived from observation and interview. 
This research has begun with an internal discussion with a group of consumers who are students at the same university. Based on the results of the discussion, there are seven places selected to observe:
a. Cafe "DE" in north Bandung
b. Cafe "UPN" in central Bandung
c. Cafe "EB" in central Bandung
d. Coffee Shop "SB" in south Bandung
e. Coffee Shop "NB" in central Bandung

From 180 questionnaires distributed, 178 respondents obtained and fill in it completely. Questionnaires are prepared in the form of closed and open questions, with the following systematics in Table 3.

Table 3. Systematic of Questionnaire

\begin{tabular}{|l|l|}
\hline Introduction & $\begin{array}{l}\text { Contains open questions regarding: } \\
\text { (i) name, (ii) age, (iii) sex, } \\
\text { (iv) employment status, (v) income status }\end{array}$ \\
\hline Content & Contains semi-closed questions regarding: \\
(1) What cafes or coffee shops which are frequently visited? \\
(2) How often (frequency) are them visited? \\
(3) Why choose that location? \\
(4) Why do not choose another place or at home? \\
(5) What comes to mind or perception of the existence of the \\
cafe and its visitors? \\
(6) What is the required budget (expenditure) to go to the \\
place? \\
(7) Are you interested in trying another place? \\
(8) What is consumer opinion about culinary development in \\
Bandung? \\
\hline Conclusion \\
Acknowledgments and request to the respondents to be re- \\
contacted if any information is unclear (there is stated the \\
phone number or ID Line of the respondents which can be \\
contacted).
\end{tabular}

\section{Results}

From total 178 respondents, $66.2 \%$ is female and $33.8 \%$ is male. Most of respondents which are $80 \%$ are students, the age ranging from 13 until 22 . The majority of the students (75\%) get the source of income from parents, while the remaining $25 \%$ get income from their jobs. They choose to go to their favorite cafes because they need a place to study and eat. The chosen place selection describe in Figure 1. The -UPN, -SB and -EB become the most three cafes want to visit by respondents. Furthermore, $62.4 \%$ quite often visit these three cafes.

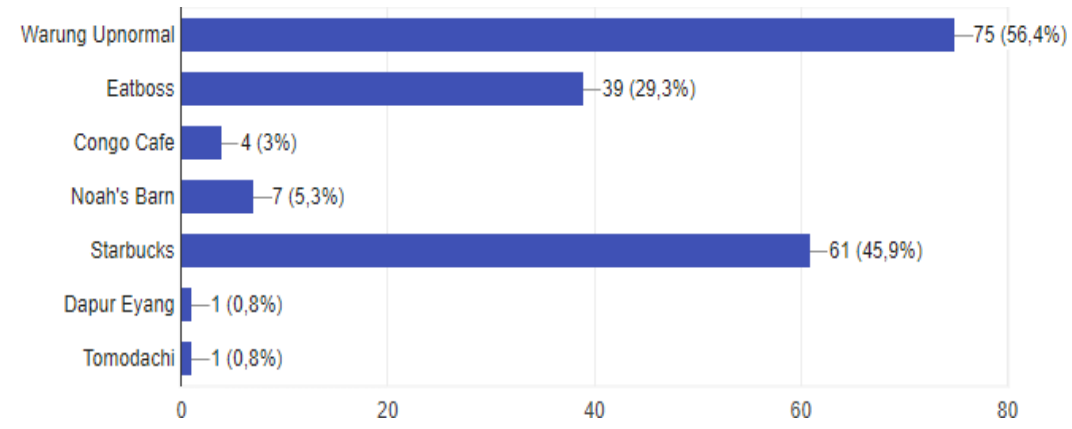

Figure 1. Chosen Café to Hangout

(Source: Manurung, E.T., Manurung, E.M., and Purwadi, Y.S., 2018) 
The reasons the respondent choose the place largely because of the comfortable factor. Most respondents are more interested in doing tasks/jobs / learning elsewhere than in the libraries because the atmosphere of libraries tend to be rigid. The respondent said that they do not believe that eating in cafes/restaurants symbolize a particular image (51.1\% of respondents). A total of 81 respondents choose culinary aspects from the taste sensation. They said that they want to eat delicious food when using their free time. 88 respondents $(66.2 \%)$ choose to come to the café to take advantage of the facilities provided. The graphic is shown in Figures 2 and 3.

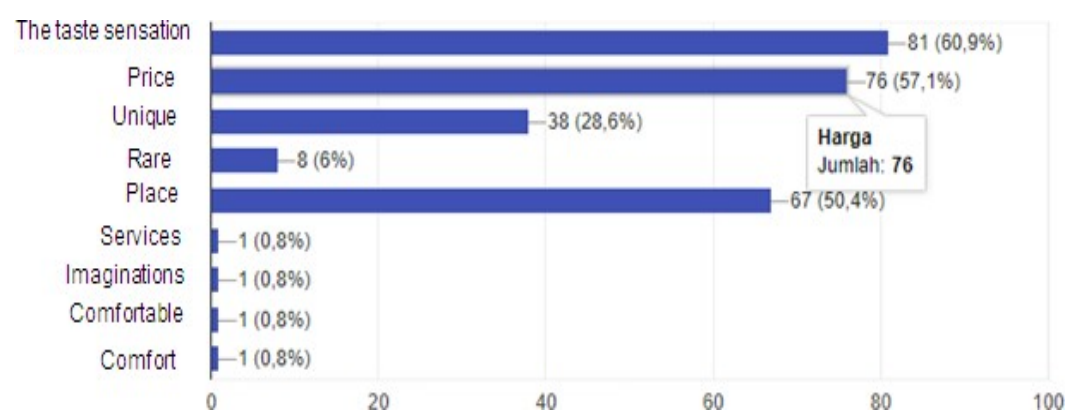

Figure 2. Reasons To Choose Café

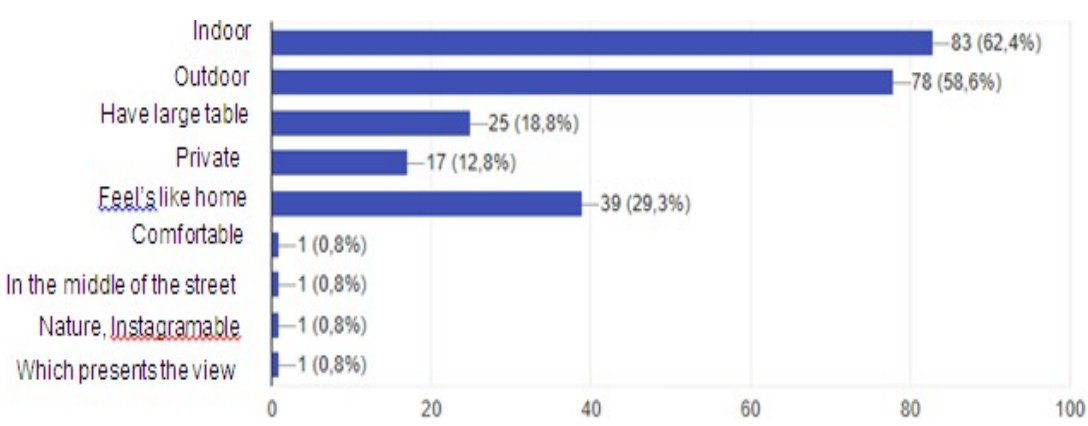

Figure 3. Choosing Café and Learning

Most of them (54.9\%) said that they do not set aside money to go to restaurants. They said that their spending budget to eat in cafes is less than IDR 500.000 per month, which number is the most spending (84.2\%). From total, $57.1 \%$ of the respondents rarely goes to the same culinary places. The reason of such thing, is because they love to experience different taste and atmosphere of other culinary places. Indoor cafe has become the favorite type of cafe of the 133 respondents. While the preferred menu when going to the cafe or restaurant is the coffee / other drinks menu. According to the respondents, Bandung is very interesting because the taste of culinary in Bandung is various and worth trying. These all opinion shown in Figure 4.

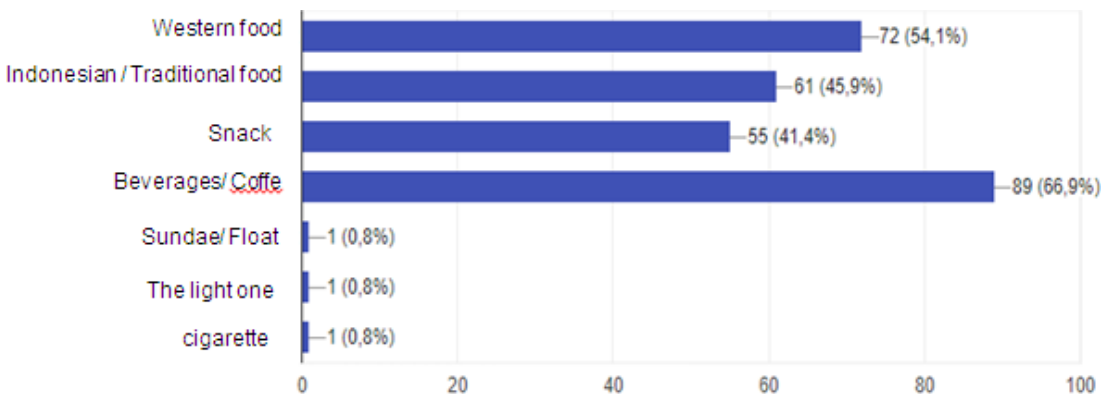

Figure 4. Chosen Majority Menus

(Source: Manurung, E.T., Manurung, E.M., and Purwadi, Y.S., 2018)

From the analysis and discussion, there are some interpretation found that reflect a new socio-cultural behavior constructed by emerging several creative-cafes today: 
(i) users are looking for a comfortable place to learn while eating, a need that has never been emerging in the past

(ii) the place selected does not always have to be a place that is hype

(iii) the most wanted café is indoor place

(iv) most café chosen by its fast $\mathrm{Wi}$-Fi, big table and comfort place to do some homework and assignments

\section{Discussion}

To examine the validity of those findings, an experiment has done to prove the findings by bringing several groups of students out of the classroom, head to the nearest café and study there. A certain course that requires field study consists of five student groups. Consensus in the class determined three of five groups agree to go to a chosen café, meet directly with the owner, and study there. Students are welcome to directly ask the owner about all material related to the course (in this case was financial management) to be asked directly to the owner. They also had the opportunity to see how certain types of coffee were made and served, how to serve customers' orders, and so on. The other 2 groups were not included in this field study because they were unable to join the schedule and they should study the materials on their own. What has been experienced and felt by the other three groups, unfortunately, cannot felt by these two other groups.

The results are quite amazing, for 3 groups who learn directly in the field (café) they look more relax and comfortable to ask and discuss. Two participants who had rarely entered the class so far and his/her attendance were not many comments, or no comments at all suddenly changed. A young man who was always busy with other matters, at that time gave many opinions and become the center of attention of his friends. As well as another female student, she requested that lecturing become more often memorized outside the classroom. Unfortunately, her request was difficult to fulfill due to the financial limitations of the lecturer. Some interviews quotes with the students are as follows:

"Ma'am, I am more relaxed here and able to get my ideas out... it's not like learning in classroom. I've always stressed... It's hard to talk and join the discussion..." (R, October 2018)

"Ma'am, I'm so glad we can go outside the classroom and study here... can we always study outside like this for the next lecture?" (P, October 2018)

Documentation during the experimental learning process is shown in Figure 5-7.

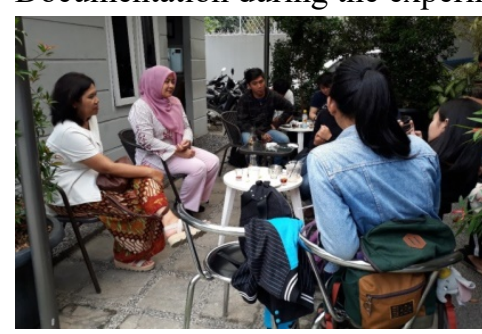

Figure 5. Experimental Learning -with Practitioners

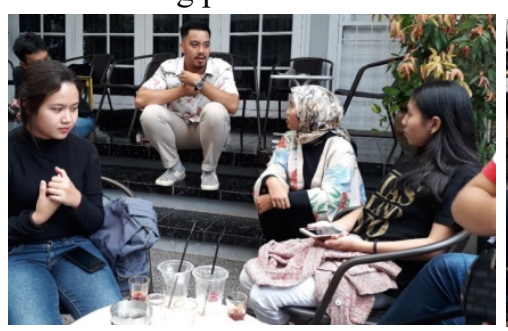

Figure 6. Experimental Learning ---passive student became active

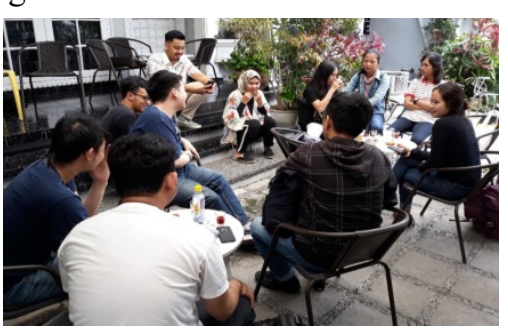

Figure 7. Experimental Learning -everybody happy

Different from previous researches that focus on emerging in cafes in Bandung as a shifting of consumers lifestyle, this study proven that cafés offer "space" or "informal space" that match with consumers --especially millennial students needed. The phenomena of -public space studying is linked to the social space produced to interpret-studying which qualitatively is almost identical to that of leisure. And in practice, this may be related to the existential function of Henri Levebvre's space, that space creates -a desire of self-exhibition. Here students have transformed the café to a versatile stage with a purpose two-fold, equal parts classroom and recreation room, studying all the while reveling in self-exhibition and available social aspect perks. The Café is sumptuous platform where showcases of prestige from one person to another are conveyed via vis-à-vis interaction. More than just a sanctuary from the mundane confines of campus life born by students, café spatial rooms were designed with the concept that you belong to a network of amity: studying together with pals and cordial friendships in mind. 
Moreover, owing to their enchanting air which invokes a sensation of ease and jocundity, this serves as a recharging mood booster of sorts for another unintentional function: the production of knowledge. In this case for consumer students the café is a veritable pleasure cruise complete with a pick-me-up to boost creativity.

\section{Conclusion}

This phenomena is also connected to representational space referring to space that is lived (lived space) as well as all forms of imagery and symbols pertaining. Representational space includes how occupants interact, practices and visualization forms within the space. The concept of space is created based upon the collection of actual experiences everyone undergoes as a cause and effect principle of a dialectic between spatial practices and space representation. Space becomes whatever is perceived by an individual, group or society: perceived space. This all explains just why students favor café's as space, these spaces vivify mood and study habits gilding the lily is the fact that these purported eateries also support audio-visual devices be they laptop, cellphones, or tablets. In such social space, students are absorbed to -dense fabric of networks and channels that contextualize production of knowledge. The café caters the imagery of erudite, cosmopolitan, and up-to-date youths, all of which are appealing. As a conceptualized space the humble café has transcended beyond its calling as a pit stop and has been reborn as an expression of academic life, combining knowledge production and mood booster, serious knowledge and playfulness. The illustrious café, make no mistake is the representative space of choice for millennial ( $\mathrm{Z}$ generation) scholars.

\section{Acknowledgments}

This research was supported by the Research and Community Service Institution of Parahyangan Catholic University. Thanks to 178 millennial students that willing to be interviewed and fill the questionnaires.

\section{References}

Fauzi, A., Punia, I.N., Kamajaya, G. (2015). Young People Hanging Out in The Café: Review of Young People Life-Style in Bali. Faculty of Social and Political Science Research Paper, Udayana University, Bali.

Gunawan, I. (2015), Etnography Research Method. Pedagogy Science Faculty. Malang Public University.

Henry, D. (2018). Marxist \& Social Constructivist Approaches to Place. Retrieved from http://pegasus.cc.ucf.edu/ janzb/courses/hum3930b/ lefebvre1. html Taken on October 16, 2018.

Hidiaz, T. (2014). Interaction of Behavior in Limited Space Environment: Case Study of Capsule Hotel The Pod, Singapore. Rekarupa, FSRD Jurnal Itenas, No. 2, Vol. 2, ISSN No. 2088-5121.

Huzari, R. (2015). Return The School Concept as A Playground (Kembalikan Konsep Sekolah Sebagai Taman). Retrieved from, http://www.babelprov.go.id/ content/kembalikan-konsep-sekolah-sebagai-taman. Taken on October 22, 2018.

Lefebvre, H. (1991). The Production of Space. Cambridge: Blackwell.

Lefebvre, H. (2008). Critique of Everyday Life: Foundations for A Sociology of the Everyday. Vol. 2. London and New York: Verso.

Manurung, E.T., Manurung, E.M., and Purwadi, Y. S. (2018), Young Entrepreneur Creativity and SocioCultural Construction of Fashion and Culinary Businesses in Bandung: A Multidisciplinary Research Report. Research Institution and Community Service of Parahyangan Catholic University (UNPAR), Bandung, Indonesia.

Pamungkas, A. S. (2016). The Production of Scape and Urban Revolution according to Henri Lefebvre. Retrieved from https://indoprogress.com/ 2016/01/produksi-ruang-dan-revolusi-kaum-urban-menuruthenri-lefebvre/ Taken on October 11, 2018.

Pramita, D.A., and Primasti, I.S. (2016). Hang out at the Coffee Shop as a Student Lifestyle in Coffee Mato Yogyakarta (Nongkrong di Warung Kopi Sebagai Gaya Hidup Mahasiswa Di Mato Kopi Yogyakarta). Journal of Sociology, University of Muhammadyah Makassar.

Pribadi, I. (2015). Hang Out at A Cafe Or Coffee Shop as Young People Lifestyle (Gaya Hidup Anak Muda Nongkrong Di Kafe Atau Kedai Kopi). Thesis and Dissertation Repository, Gajah Mada University, Yogyakarta.

Wahidah, N. (2013). Consumptive Behavior Effect on Student Lifestyle (Pengaruh Perilaku Konsumtif Terhadap Gaya Hidup Mahasiswa) Economics Faculty of FKIP UNTAN. Research Article at Tanjungpura University, Pontianak, Indonesia. 